\title{
A geological section through the southern part of the Ilímaussaq intrusion
}

\section{Steen Andersen, Henning Bohse and Agnete Steenfelt}

Detailed mapping of the southern part of the Ilimaussaq intrusion was initiated in 1968 with preparation of a map of the kakortokite at a scale of approximately 1:10 000 (Bohse $e t$ al., 1971). Other small areas south of Tunugdliarfik have been mapped and described in detail (Demin, 1971; Demina, 1979; Steenfelt, 1981), and at present these results, together with additional mapping by S. Andersen and H. Bohse (Andersen \& Bohse, 1978; Bohse \& Andersen, 1981) of the area between Tunugdliarfik and Kangerdluarssuk-Lakseelv, are being compiled at a scale of 1:5000.

The information obtained, along with the mapping, on the spatial relations of the involved rock units has allowed the authors to construct two generalised profiles through the upper and lower series of rocks, respectively (figs $1 \& 2$ ).

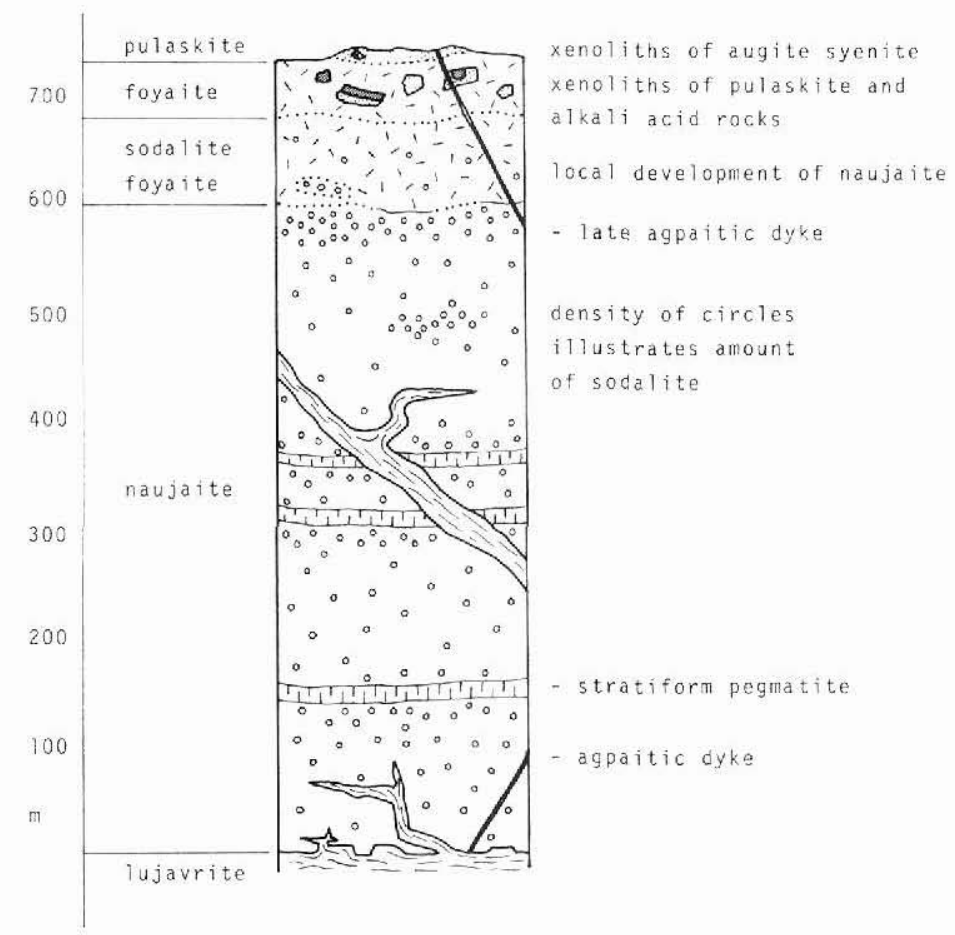

Fig. 1. Schematic profile of the upper series of the Ilímaussaq intrusion in the area between Tunugdliarfik and Kangerdluarssuk. Dotted lines indicate transitional boundaries. 


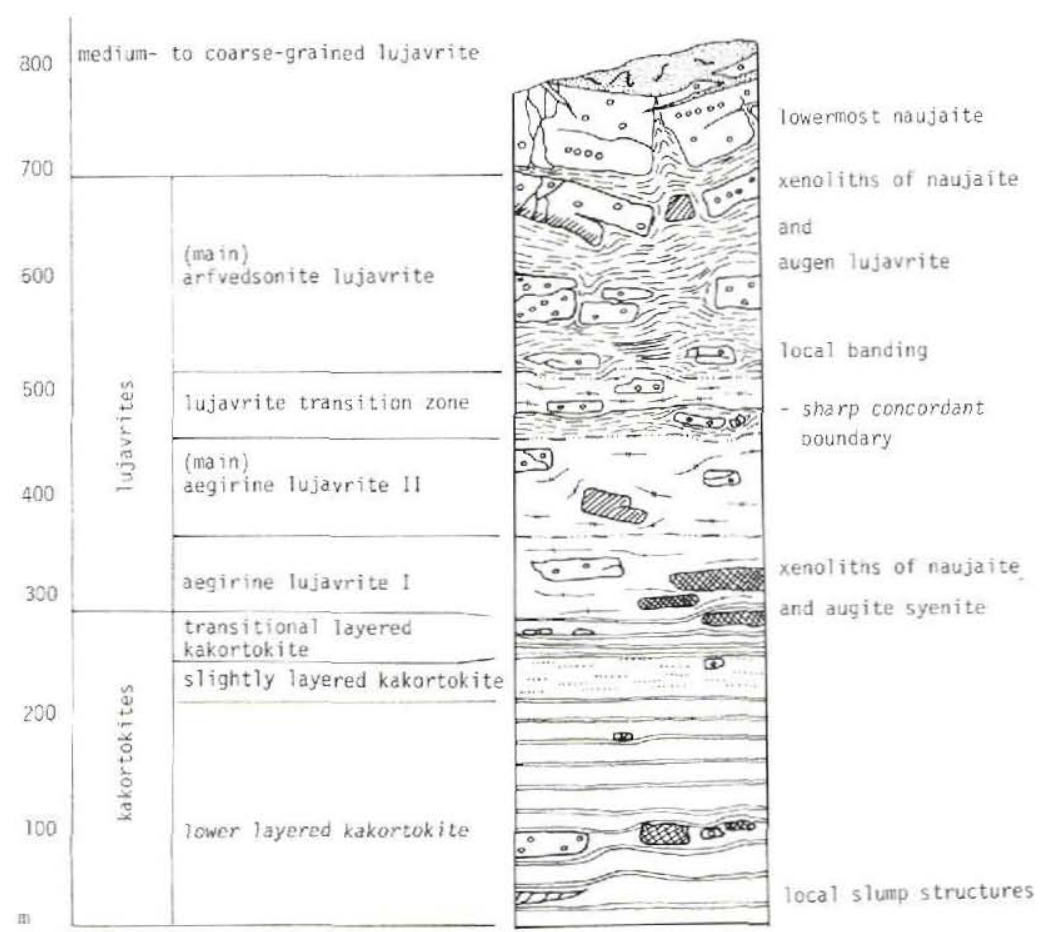

Fig. 2. Schematic profile of the lower series of the Ilimaussaq intrusion in the area from Agpat to Kringlerne.

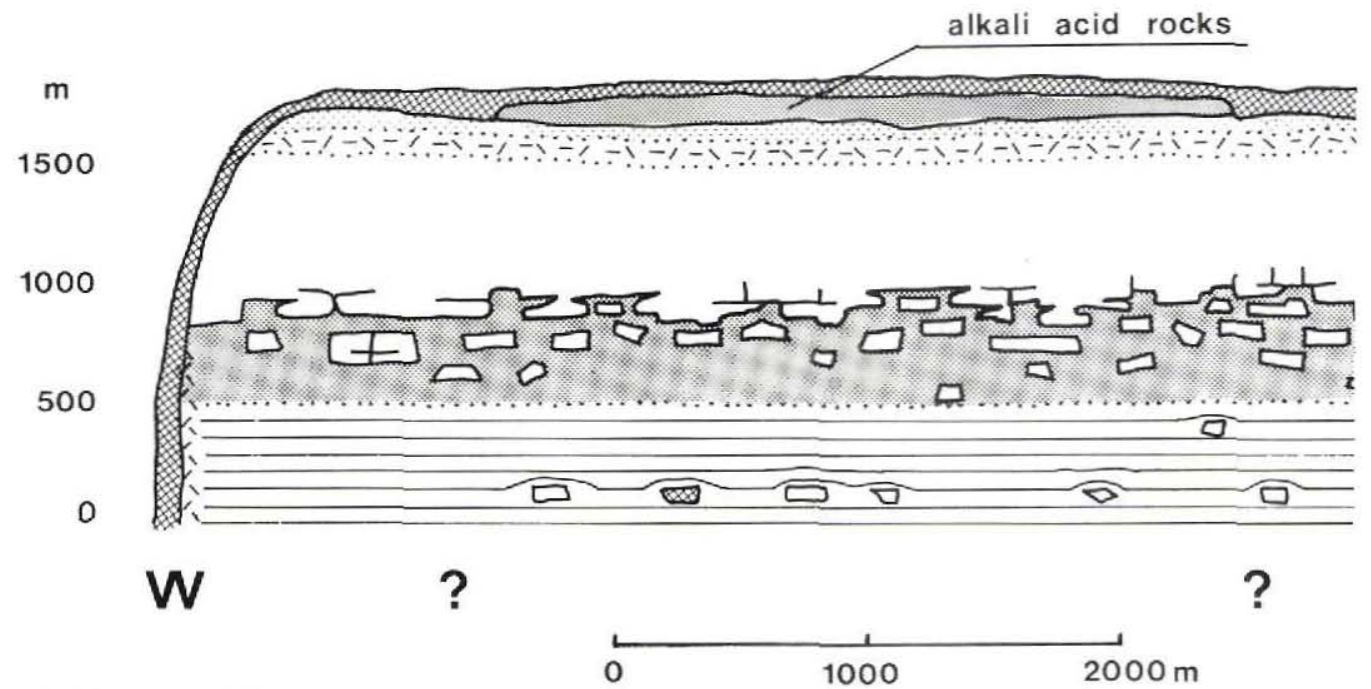

Fig. 3. Diagrammatic E-W cross-section of the southern part of the Ilimaussaq intrusion. The vertical 
Table 1. Estimated thicknesses and volume percentages of the rock units of the southern part of the Ilimaussaq intrusion

\begin{tabular}{|c|c|c|c|c|c|}
\hline & \multicolumn{3}{|c|}{ Thickness m } & \multirow{2}{*}{$\begin{array}{l}\text { volume } \% \text { of } \\
\text { individusl } \\
\text { series }\end{array}$} & \multirow{2}{*}{$\begin{array}{l}\text { volume } \\
\text { complete } \\
\text { sequence }\end{array}$} \\
\hline & $\begin{array}{l}\text { Average } \\
\text { this paper }\end{array}$ & Uasing $(1912)$ & Ferguson $(1970\rangle$ & & \\
\hline \multicolumn{6}{|l|}{ Upper series } \\
\hline $\begin{array}{l}\text { alkali acid rocks } \\
\text { pulaskite } \\
\text { foyaite } \\
\text { godalite foyaite } \\
\text { naujaite }\end{array}$ & $\begin{array}{r}750 \\
20 \\
60 \\
80 \\
600 \\
760\end{array}$ & $\begin{array}{c}10-30 \\
0-10 \\
2-150 \\
200-600\end{array}$ & $\begin{array}{c}60 \\
500-800\end{array}$ & $\begin{array}{l}\text { not incor } \\
3 \\
8 \\
10 \\
\frac{79}{100}\end{array}$ & $\begin{array}{r}\text { porated } \\
1 \\
4 \\
6 \\
42 \\
53\end{array}$ \\
\hline \multicolumn{6}{|l|}{ Lower series } \\
\hline $\begin{array}{l}\mathrm{m}-\mathrm{c} \text { lujavrite } \\
\text { main arfvedsonite lujavrite } \\
\text { lujavrite transition zone } \\
\text { upper geg. lujavrite II } 35 \text { II } \\
\text { lower arf. lujavite } 25 \\
\text { main aegirine lujavrite II } \\
\text { aegirine lujavrite I } \\
\text { trangitional layered kakortokite } \\
\text { slightly layered kakortokite } \\
\text { lower layered kakortokite } \\
\text { (exposed part) }\end{array}$ & $\begin{array}{r}35 \\
80 \\
40 \\
35 \\
210 \\
660\end{array}$ & 600 & $\left\{\begin{array}{l}200 \\
150 \\
400\end{array}\right.$ & $\begin{array}{l}\text { not incor } \\
23 \\
9\end{array}$ & $\begin{array}{r}\text { porated } \\
11 \\
4\end{array}$ \\
\hline
\end{tabular}

Further, a new and more accurate estimation of thicknesses and volumes of the rock sequence is presented in Table 1. Earlier estimates of this kind have been given by Ussing (1912) and Ferguson (1970). The rock units mentioned are described by the authors elsewhere in this volume (Bohse \& Andersen; Steenfelt).

The alkali acid rocks and the M-C lujavrite are excluded from the estimates of Table 1, because their original dimensions have been much reduced by erosion.

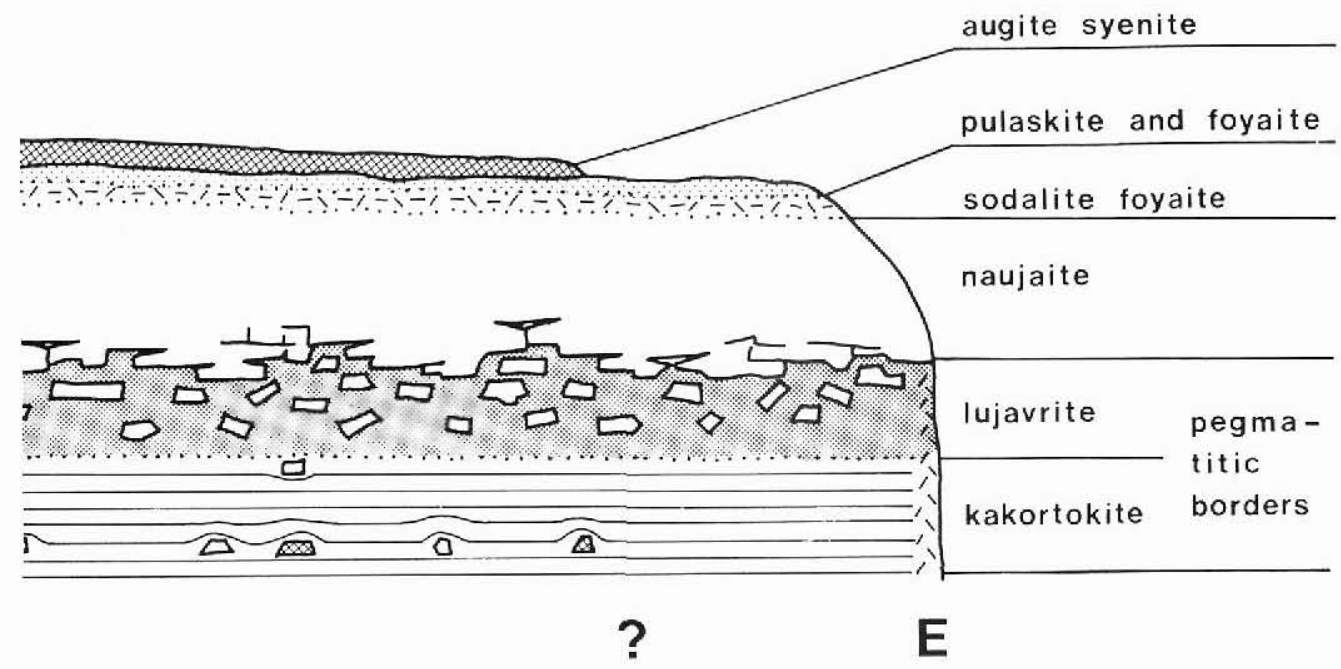

and horizontal scales are equal. 
The thicknesses and volumes estimated for the units of the lower series (Table 1) include varying amounts of naujaite and augite syenite xenoliths. Xenoliths of naujaite may constitute up to 20 per cent of the volume of the lujavrite (fig. 2).

The average thickness of the main arfvedsonite lujavrite is difficult to estimate because the real thickness varies from a few to $250-300 \mathrm{~m}$, and the contact against the overlying naujaite is extremely irregular.

As an approximation in the volume calculation, the indicated thicknesses are assumed to remain constant throughout the southern part of the intrusion.

An almost complete cross section through the southern part of Ilímaussaq is visualised by combining the two profiles of figs $1 \& 2$. In the reconstruction (fig. 3), illustrating the vertical as well as the lateral extent of the main rock units, all structural disturbances caused by later magmatic or tectonic events are disregarded. The indicated extent of the augite syenite and of the alkali acid rocks of the roof is entirely arbitrary.

\section{References}

Andersen, S. \& Bohse, H. 1978: Field work on the kakortokites and lujavrites in the Ilímaussaq intrusion, South Greenland. Rapp. Grønlands geol. Unders. 90, 73-75.

Bohse, H. \& Andersen, S. 1981: Review of the stratigraphic divisions of the kakortokite and lujavrite in southern Ilímaussaq. Rapp. Grønlands geol. Unders. 103 (this volume).

Bohse, H., Brooks, C. K. \& Kunzendorf, H. 1971: Field observations on the kakortokites of the Ilímaussaq intrusion, South Greenland, including mapping and analyses by portable X-ray fluorescence equipment for zirconium and niobium. Rapp. Grønlands geol. Unders. 38, $43 \mathrm{pp}$.

Demin, A. 1971: Detailed mapping in the southern part of the Ilímaussaq intrusion (Kangerdluarssuk fjord). Rapp. Grønlands geol. Unders. 35, 29-30.

Demina, A. 1979: Field geology and petrography of the upper kakortokites and a section through the lujavrites of the Ilimaussaq intrusion, South Greenland. Unpubl. int. GGU report, $52 \mathrm{pp}$.

Ferguson, J. 1970: The significance of the kakortokite in the evolution of the Ilímaussaq intrusion, South Greenland. Bull. Grønlands geol. Unders. 89 (also Meddr Grønland 190,1) 193 pp.

Steenfelt, A. 1981: Field relations in the roof zone of the Ilímaussaq intrusion with special reference to the position of the alkali acid rocks. Rapp. Gronlands geol. Unders. 103 (this volume).

Ussing, N. V. 1912: Geology of the country around Julianehaab, Greenland. Meddr Grønland 38, $376 \mathrm{pp}$.

A.S.,

Grønlands Geologiske Undersøgelse,

$\emptyset$ ster Voldgade 10,

DK-1350 Copenhagen $K$.
S.A., H.B., Institut for Petrologi, University of Copenhagen, $\emptyset$ ster Voldgade 10, DK-1350 Copenhagen K. 